\title{
Coal Consumption and Environmental Sustainability in South Africa: The role of Financial Development and Globalization
}

\author{
Tomiwa Sunday Adebayo $a^{*}$, Dervis Kirikkalelib, Ibrahim Adesholac, Dokun \\ Oluwajana $^{d}$, Gbenga Daniel Akinsolae, Oseyenbhin Sunday Osemeahon ${ }^{f}$ \\ ${ }^{a}$ Faculty of Economics and Administrative Science, Department of Business Administration, Cyprus International University,
Northern Cyprus, TR-10 Mersin Turkey \\ ${ }^{b}$ Faculty of Economic and Administrative Sciences, Department of Banking and Finance, European University of Lefke, Northern \\ Cyprus TR-10 Mersin, Turkey \\ ${ }^{c}$ School of computing and technology, Department of Information Technology, Eastern Mediterranean University, Northern \\ Cyprus, Mersin 10-Turkey \\ ${ }^{d}$ Faculty of applied science, Department of Management information systems, Cyprus international university, Northern Cyprus, \\ Mersin 10-Turkey \\ ${ }^{e}$ Faculty of Economics and Administrative Sciences, Department of Business, Management, Girne American University, Northern \\ Cyprus, Mersin 10-Turkey
}

fSchool of Applied Sciences, Department of Management Information Systems, , Cyprus International University, Nicosia, Northern Cyprus, TR-10 Mersin Turkey

\begin{abstract}
This paper aims to investigate coal consumption and environmental sustainability in South Africa by examining the role of financial development and globalization by using a dataset covering the period from 1980 to 2017. The study utilized the Auto-regressive Distributed Lag Model (ARDL) approach in addition to the Bayer and Hank combined co-integration, fully modified Ordinary least squares (FMOLS), and Dynamic ordinary least Squares (DOLS). The study further utilized the frequency domain causality test to capture the causal linkage between the series. The advantage of the frequency domain causality is that it can capture causal linkages between series at different periods. The Bayer and Hanck co-integration and ARDL bounds tests reveal co-integration among the series. The empirical findings based on the ARDL long-run estimation reveal that a $1 \%$ increase in coal consumption increases environmental degradation by $1.077 \%$, while a $1 \%$ increase in financial development decreases the environmental degradation by $0.973 \%$. Furthermore, a $1 \%$ increase in economic growth decreases environmental quality by $1.449 \%$. The outcomes of the FMOLS and DOLS approaches also provide supportive evidence for the ARDL long-run results. Furthermore, the results of the frequency domain causality test reveal that at a significance level of $1 \%$, coal consumption Granger causes $\mathrm{CO}_{2}$ emissions at different frequencies, while financial development Granger causes $\mathrm{CO}_{2}$ emissions in the long run and short run at a significance level of $10 \%$. In terms of policy suggestions, South Africa should embrace policies that encourage energy consumers to shift toward renewable energy. Furthermore, financial reforms should be implemented to curb environmental degradation.
\end{abstract}

Keywords: $\mathrm{CO}_{2}$ Emissions; Coal Consumption; Economic Growth; Financial Development; Globalization; South-Africa

Article History: Received: $14^{\text {th }}$ December 2020; Revised: $15^{\text {th }}$ February 2021; Accepted: 1 ${ }^{\text {st }}$ March 2021; Available online: $10^{\text {th }}$ March 2021 How to Cite This Article: Adebayo, T.S., Kirikkaleli, D., Adeshola, I., Oluwajana, D., Akinsola, G.D., Osemeahon, O.S. (2021) Coal Consumption and Environmental Sustainability in South Africa: The role of Financial Development and Globalization. International Journal of Renewable Energy Development, 10(3), 527-536.

https://doi.org/10.14710/ijred.2021.34982

\section{Introduction}

The famous saying that pollution is an issue for developing countries and not for developed nations is no longer valid, at least in terms of its implications. The predominant use of coal in developed and developing economies is aimed at meeting the high demand for energy consumption. Additionally, coal is more available and costeffective compared to other forms of energy. Globally, coal is the second-largest energy source, accounting for close to
$30 \%$, and is primarily used for power generation, with more than $40 \%$ used in the generation of electricity (Adedoyin et al. 2020). The rise in demand for coal releases increased energy pollutants, which causes a potential threat to human health and the environment. This environmental pollution is a global problem, and the earth is exposed to threats arising from the degradation of environmental conditions (Adebayo, 2021). Thus, the obligation to save the planet from such problems falls

\footnotetext{
${ }^{*}$ Corresponding author: twaikline@gmail.com
} 
primarily to countries that are the major producers of carbon dioxide emissions.

In the Sub-Saharan region, South Africa is the biggest producer and exporter of coal, ranked fifth in terms of global consumption, and about $85.7 \%$ of the country's main energy needs are provided by coal (EIA, 2020). According to Shahbaz, Tiwari, and Nasir (2013), coal is a major energy source in South Africa and constitutes $1 \%$ of global emissions, while the average rate of economic growth in South Africa increased from 1.4\% in 2017 to $1.9 \%$ in 2020 (World Bank, 2018). Global efforts to minimize global $\mathrm{CO}_{2}$ emissions depend heavily on collective efforts to reduce emissions. However, difficulties may occur for countries where $\mathrm{CO}_{2}$ emissions are connected to energy production because energy is a driver of economic development.

In South Africa, reducing $\mathrm{CO}_{2}$ emissions will inevitably slow down the country's economic growth, which is why many countries are very reluctant to implement measures to constrain such emissions. South Africa's financial development has been on the rise, which has been accompanied by an increase in the country's $\mathrm{CO}_{2}$ emissions; furthermore, it has had a robust financial base since 1994, and this has continued in an upward direction, apart from in 2007 during the financial crisis that severely affected the country. Since then, fiscal and economic growth has been stable and its level of energy consumption has been increasing (Shahbaz et al. 2013). Accordingly, the financial development of South Africa is primarily dependent on the use of financial resources by the South Africans to improve the country's financial and economic growth - to increase energy efficiency, improve enterprise performance, business opportunities, investment efficiency, exchange of goods and services, reduce $\mathrm{CO}_{2}$ emissions and develop technology and energy. On this basis, there has been a continuous and increasing demand for the development of the South African energy and environment sector. From this perspective, there are few empirical studies on the subject matter, particularly those that focus on financial improvement, economic growth, and the demand for coal consumption in South Africa. Among the few studies carried out on the field, Joshua and Bekun (2020) called for more pragmatic approaches to extricate economic growth from $\mathrm{CO}_{2}$ emissions in South Africa's energy policy.

Over the years, several studies have been conducted regarding the association between $\mathrm{CO}_{2}$ emissions, financial development, globalisation and coal consumption. For instance, Belaid and Youssef (2017) provided evidence that non-renewable energy deteriorates Algeria's environmental quality. Also, Attiaoui et al. (2017) analyzed the effect of clean and non-renewable energy on ecological emission levels in 22 African countries by applying the ARDL techniques. The investigators found that non-renewable energy contributes significantly to environmental pollution and clean energy reduces pollution. Also, Sarkodie and Adams (2018) confirmed that non-renewable energy increases pollution in South Africa. Coal continues to be the primary energy source for emerging economies, and South Africa is not excluded from the list of top coal-consuming countries. The study of Joshua and Bekun (2020) supported the environmental Kuznets curve (EKC) hypothesis that there is a feedback relationship between $\mathrm{CO}_{2}$ emissions and revenue (GDP).
Likewise, Joshua et al. (2020) established that economic growth exerts a positive influence on $\mathrm{CO}_{2}$ emissions. According to Odhiambo (2016), there are consistent $\mathrm{CO}_{2}$ emissions in South Africa that are traced to rapid economic growth. Furthermore, prior studies have also reported that a rise in economic growth raises $\mathrm{CO} 2$ emissions (Akinsola \& Adebayo, 2021). Similarly, in the study conducted by Adebayo (2020), the frequency domain technique adopted revealed a feedback causality between growth and $\mathrm{CO}_{2}$ in Mexico. In Turkey, Kirikkaleli and Kalmaz (2020) studied the interconnection between $\mathrm{CO}_{2}$ emissions and the economy, revealing that an increase in environmental degradation accompanies an increase in economic growth.

Regarding the linkage between financial development and economic growth, several studies have been conducted. For instance, Ozatac et al. (2017) examined the environmental Kuznets curve (EKC) hypothesis for the case of Turkey and found that financial development did not affect $\mathrm{CO}_{2}$ emissions, whereas energy consumption, trade openness, and urbanization increased $\mathrm{CO}_{2}$ emissions. Furthermore, Pata (2018a) also utilized the ARDL bounds test for the period from 1974 to 2013 and confirmed the EKC hypothesis's validity. The author reported that financial development increased $\mathrm{CO}_{2}$ emissions. Similarly, Pata (2018b) reported that financial development increased $\mathrm{CO}_{2}$ emissions. Shahbaz et al. (2013) studied the relationship between financial development, economic growth, trade openness, $\mathrm{CO}_{2}$ emissions, and coal consumption in South Africa, and their findings clearly showed that financial development minimizes $\mathrm{CO}_{2}$ emissions. Umar et al. (2020) employed the Bayer-Hanck co-integration and wavelet coherence approaches to examine the determinants of $\mathrm{CO}_{2}$ emissions in China. Their study revealed that there are negative correlations between financial development and $\mathrm{CO}_{2}$ emissions in the long run.

Odugbensan and Adebayo (2020) recently examined the interconnection between financial development and environmental sustainability in Nigeria and their empirical findings showed that environmental sustainability in Nigeria has been harmed by financial development. This result was not in agreement with the outcome of Adebayo and Odugbesan (2020), who utilized the wavelet coherence method to gather information on the correlation and causal relationship between financial development, real growth, and urbanization, and $\mathrm{CO}_{2}$ emissions in South Africa and they found that financial development impacts $\mathrm{CO}_{2}$ emissions positively in South Africa.

Globalization is the last factor considered in our study, which has been shown to facilitate the transition of advanced technologies from industrialized to emerging economies, aids in fostering the division of work, and improves the economic benefit of different countries. Globalization enhances economic growth through foreign direct investment and technological innovations from industrialized countries to developing countries. Liu et al. (2020) examined the relationship between globalization and $\mathrm{CO}_{2}$ emissions in the $\mathrm{G} 7$ countries. Their analysis showed that the connection between globalization and $\mathrm{CO}_{2}$ emissions is an inverted U-shaped, strongly confirmed by the environmental Kuznets curve hypothesis. Similarly, Nguyen and Le (2020) explored the effect of globalization on $\mathrm{CO}_{2}$ emissions in Vietnam. The authors used the ARDL 
technique on time series data for the period from 1990 to 2016. Their analysis showed that globalization is causing $\mathrm{CO}_{2}$ emissions to increase in Vietnam, and therefore, globalization is not advantageous for long-term environmental health. Contrarily, Khan et al. (2019) analyzed the effect of globalization, economic factors, and energy use on $\mathrm{CO}_{2}$ emissions in Pakistan from 1971 to 2016 using the dynamic ARDL simulation model. The outcomes of the dynamic ARDL simulations revealed that energy use, financial growth, foreign direct investment, trade, economic globalization, political globalization, and social globalization significantly impact $\mathrm{CO}_{2}$ emissions in Pakistan.

Based on the reviewed studies, it is evident that they have produced mixed findings. Thus, this study takes it a step further by including the financial development index, which is a broader measure of financial development.

\section{Materials and Methods}

\subsection{Materials}

This study examines the impact of coal consumption, economic growth, financial development, and globalization on $\mathrm{CO}_{2}$ emissions in South Africa. This study uses data from 1980 to 2018 on an annual basis. In this analysis, all indicators are converted into their normal logarithms. This is done to ensure that the data comply with normality (Adebayo and Demet 2020). Table 1 illustrates the unit of measurement, source, and description of data. Furthermore, Figures 1, 2 and 3 depict the trend of key variables in this study.

In line with Shahbahz et al. (2013), the economic function, economic model, and econometric model of the analysis are represented in Equations 1, 2, and 3, respectively.

$$
\begin{aligned}
& C O_{2 t}=f\left(C C_{t}, F D_{t}, G L O_{t}, G D P_{t}\right) \\
& C O_{2 t}=\vartheta_{0}+\vartheta_{1} C C_{t}+\vartheta_{2} F D_{t}+\vartheta_{3} G L O_{t}+\vartheta_{4} G D P_{t} \\
& C O_{2 t}=\vartheta_{0}+\vartheta_{1} C C_{t}+\vartheta_{2} F D_{t}+\vartheta_{3} G L O_{t}+\vartheta_{4} G D P_{t}+e_{t}
\end{aligned}
$$

In Equations 1, 2, and 3, $\mathrm{CO}_{2}, \mathrm{CC}, \mathrm{FD}, \mathrm{GLO}$, and GDP illustrate $\mathrm{CO}_{2}$ emissions, coal consumption, financial development, globalization, and economic growth, respectively. Coal consumption is expected to exert a positive impact on $\mathrm{CO}_{2}$ emissions. Thus, coal consumption will deteriorate the quality of the environment, i.e., $\left(\vartheta_{1}=\right.$ $\left.\frac{\partial \mathrm{CO}_{2}}{\partial C C}>0\right)$. Financial development is expected to negatively impact $\mathrm{CO}_{2}$ emissions. Thus, an increase in financial development will also increase environmental sustainability, i.e., $\left(\vartheta_{2}=\frac{\partial \mathrm{CO}_{2}}{\partial F D}<0\right)$ otherwise $\left(\vartheta_{2}=\frac{\partial \mathrm{CO}_{2}}{\partial F D}>\right.$ $0)$. It is anticipated that the interconnection between globalization and $\mathrm{CO}_{2}$ emissions will be negative. Thus, a rise in GLO will improve the quality of the environment, i.e., globalization $\left(\vartheta_{3}=\frac{\partial C O_{2}}{\partial G L O}<0\right)$ otherwise $\left(\vartheta_{3}=\frac{\partial C O_{2}}{\partial G L O}>\right.$ $0)$. Economic growth is expected to increase $\mathrm{CO}_{2}$ emissions. Therefore, a rise in economic growth will deteriorate environmental quality, i.e., $\left(\vartheta_{4}=\frac{\partial C O_{2}}{\partial G D P}>0\right)$.

\section{Economic Growth}

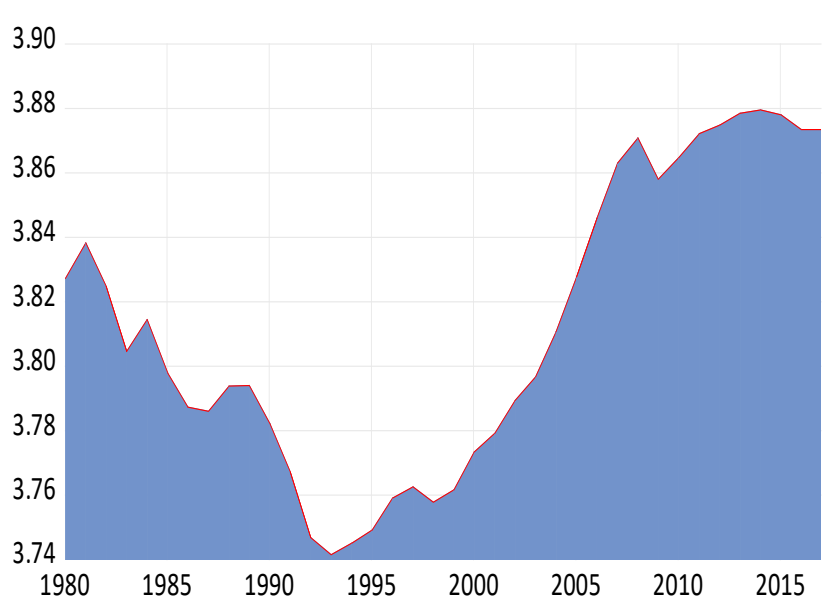

Fig 1. Economic Growth in South Africa from 1980 to 2017

\section{Coal Consumption}

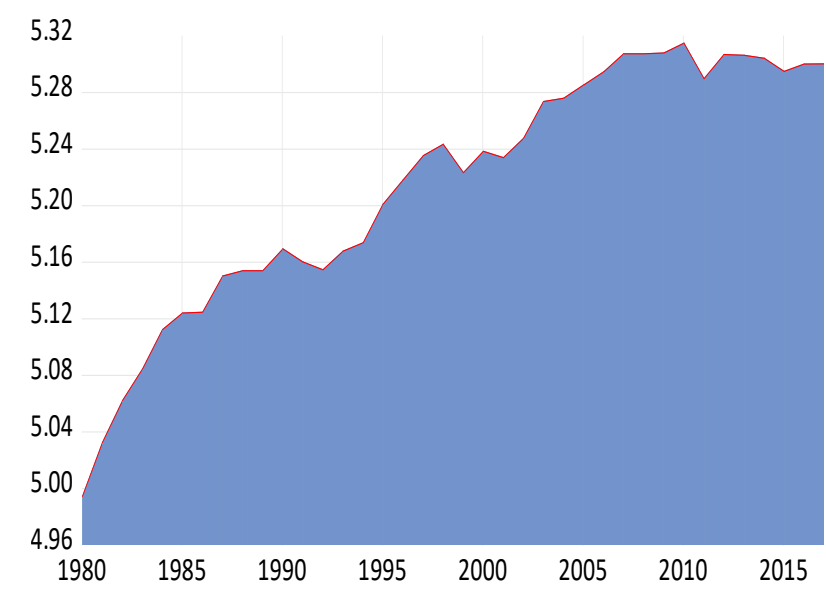

Fig 2. Coal Consumption in South Africa from 1980 to 2017

\section{CO2 Emissions}

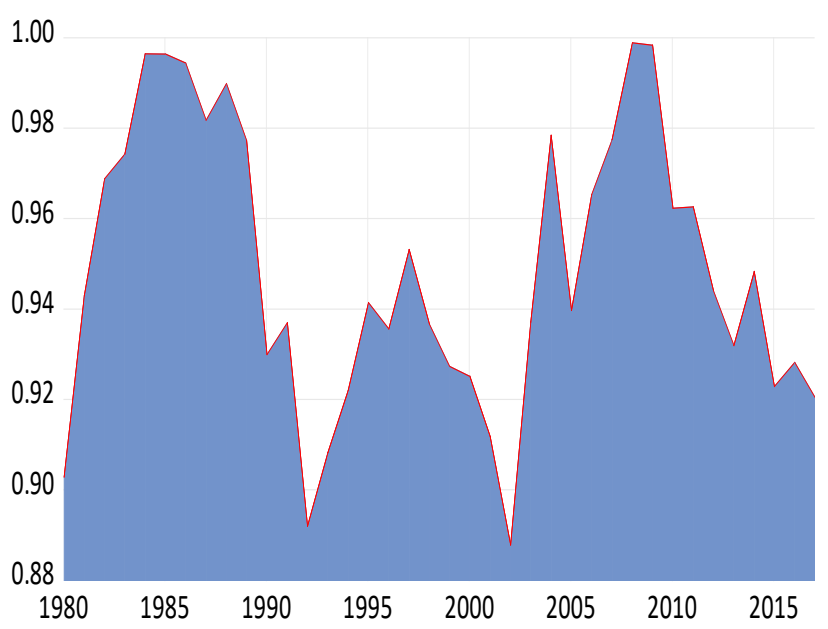

Fig 3. $\mathrm{CO}_{2}$ Emissions in South Africa from 1980 to 2017 
Citation: Adebayo, T.S., Kirikkaleli, D., Adeshola, I., Oluwajana, D., Akinsola, G.D., Osemeahon, O.S. (2021) Coal Consumption and Environmental Sustainability in South Africa: The role of Financial Development and Globalization. Int. Journal of Renewable Energy Development, 10(3), 527-536, doi: 10.14710/ijred.2020.34982

$\mathrm{P}$ a g e 1530

Table 1

Data Description and Units

\begin{tabular}{|c|c|c|}
\hline Variables & Unit & Measurements \\
\hline \multirow[t]{2}{*}{$\mathrm{CO}_{2}$} & Carbon & Metric \\
\hline & Emissions & tonnes of $\mathrm{CO}_{2}$ \\
\hline \multirow[t]{2}{*}{ GDP } & Gross & \\
\hline & $\begin{array}{l}\text { Domestic } \\
\text { Product }\end{array}$ & Constant US Dollars, 2010 \\
\hline \multirow[t]{2}{*}{$\mathrm{CC}$} & Coal & Million Tonnes of Oil \\
\hline & Consumption & Equivalent (Mtoe) \\
\hline \multirow[t]{3}{*}{ FD } & Financial & A broad measure for financial \\
\hline & Development & development by taking into \\
\hline & & accessibility, and depth \\
\hline \multirow[t]{3}{*}{$\mathrm{GlO}$} & Economic & Index-Based on FDI, trade and \\
\hline & Globalization & portfolio investment \\
\hline & Index & \\
\hline
\end{tabular}

Source: WDI (2020), IMF (2020), and Gygli, et al. (2019)

\subsection{Methods}

\subsubsection{Unit Root Tests}

It is essential to examine the order of integration of the series before conducting further analysis. Thus, the study evaluates the integration features of the series by employing unit root tests. First, the study uses the conventional augmented Dickey-Fuller (ADF) and Phillips-Perron (PP) unit root tests. Second, due to structural break(s) in series, traditional unit root tests can produce inaccurate results. Therefore, the study uses the unit root tests developed by Zivot and Andrews (2002) and Lee, and Strazicich (2004), which can simultaneously capture the stationarity features of the series and the structural break(s).

\subsubsection{Bayer and Hanck Combined Cointegration Test}

This research further uses the integrated cointegration test of Bayer and Hanck (2013) as a rigorous co-integration test, which is a combination of the Banerjee et al. (1998), Boswijk (1995), Johansen (1991), and Engle and Granger (1987) co-integration tests. According to Abdullah et al. (2021) and Kirikkaleli and Kalmaz (2020), the combined co-integration test focuses on eliminating unnecessary extensive testing methods generated by other co-integration tests. In constructing the co-integration test, Bayer and Hanck (2013) used the Fisher formula to implement the test. The Bayer and Hanck (2013) equations are depicted as follows:

$$
\begin{aligned}
E G-J O H=-2[ & \ln (P E G)+\ln (P J O H)] \\
E G-J O H-B O- & B D \\
& =-2[\ln (P E G)+\ln (P J O H)+\ln (P B O) \\
& +\ln (P B D M)]
\end{aligned}
$$

Where PEG indicates the level of significance for Engle and Granger (1987), and PJOH refers to the level of significance for Johansen (1991). The significance levels for the co-integration tests of Boswijk (1994) and Banerjee et al. (1998) are expressed by PBO and PBDM, respectively.

\subsubsection{ARDL Approach}

To verify the combined cointegration test, the researchers utilized the ARDL bounds test to capture the co-integration amongst the series. The bounds test of Pesaran et al. (2001) is preferred over other co-integration tests due to the following reasons. Firstly, it can be utilized when series are integrated of mixed order; secondly, it is significantly more reliable, particularly for small sample sizes (Kirikaleli and Adebayo, 2021); and thirdly, it offers accurate estimations of the long-term model. The bounds test follows the F-distribution, and its critical values were proposed by Pesaran and Timmermann (2005). Pesaran et al. (2001) illustrated the ARDL bounds test as follows in Equation 6.

$$
\begin{aligned}
\Delta C O_{2 t}=\vartheta_{0}+\beta_{1} C O_{2 t-1}+\beta_{2} C C_{t-1}+\beta_{3} F D_{t-1}+\beta_{4} G L O_{t-1} \\
+\beta_{5} G D P_{t-1} \sum_{i=1}^{t} \vartheta_{1} \Delta C O_{2 t-i} \\
+\sum_{i=1}^{t} \vartheta_{2} \Delta C C_{t-i}+\sum_{i=1}^{t} \vartheta_{3} \Delta F D_{t-i} \\
+\sum_{i=1}^{t} \vartheta_{4} \Delta G L O_{t-i}+\sum_{i=1}^{t} \vartheta_{5} \Delta G D P_{t-i} \\
+\varepsilon_{t}
\end{aligned}
$$

The null hypothesis and the alternative hypotheses are no co-integration and evidence of co-integration, respectively. The study fails to accept the null hypothesis since the F-statistics is more than the lower and upper bound critical values. As illustrated by Pesaran et al. (2001), the null and alternative hypotheses are depicted in Equations 7 and 8.

$H_{0}=\vartheta_{1}=\vartheta_{2}=\vartheta_{3}=\vartheta_{4}=\vartheta_{5}$

$H_{a} \neq \vartheta_{1} \neq \vartheta_{2} \neq \vartheta_{3} \neq \vartheta_{4} \neq \vartheta_{5}$

Where $H_{0}$ denotes the null hypothesis and $H_{a}$ illustrates the alternative hypothesis. The study utilizes the criteria of Kripfganz and Schneider (2018), which require the generated T-statistics and F-statistics to be higher than the corresponding upper critical values, an essential requirement for deciding on co-integration, unlike the prior decision-making criteria that require the F-statistic to be higher than the upper critical values for co-integration. Additionally, the p-values produced should be below the target levels.

After co-integration among the parameters is confirmed, the study utilizes the ARDL approach. After the long-term linkages have been identified, short-term interconnections are investigated using the Error Correction Model (ECM) developed by Engle and Granger (1987) for the assessment of short-term coefficients and the Error Correction Term (ECT). According to Pesaran et al. (2001), this is done by integrating the ECM into the ARDL framework as shown in Eq 9. 


$$
\begin{aligned}
\Delta C O_{2 t}=\vartheta_{0}+\beta_{1} C O_{2 t-1}+\beta_{2} C C_{t-1}+\beta_{3} F D_{t-1}+\beta_{4} G L O_{t-1} \\
+\beta_{5} G D P_{t-1} \sum_{i=1}^{t} \vartheta_{1} \Delta C O_{2 t-i} \\
+\sum_{i=1}^{t} \vartheta_{2} \Delta C C_{t-i}+\sum_{i=1}^{t} \vartheta_{3} \Delta F D_{t-i} \\
+\sum_{i=1}^{t} \vartheta_{4} \Delta G L O_{t-i}+\sum_{i=1}^{t} \vartheta_{5} \Delta G D P_{t-i} \\
+\rho E C T_{t-i} \\
+\varepsilon_{t}
\end{aligned}
$$

Where the speed of adjustment is depicted by $\rho$ and the error correction term is depicted by $E C T_{t-1}$.

\subsubsection{FMOLS and DOLS Long-run Estimators}

To confirm the outcomes of the ARDL long-run estimates, the study employs the FMOLS and DOLS tests. While various econometric approaches can be used to evaluate the long-run interconnection between variables, the Fully Modified OLS (FMOLS) introduced by Phillips and Hansen (1990) and the Dynamic OLS (DOLS) approach developed by Stock and Watson (1993) are used in this analysis. These methods permit asymptotic coherence to be obtained by considering the impact of serial correlation. FMOLS and DOLS can only be done if there is proof of co-integration between the series. Therefore, long-term elasticity is calculated with FMOLS and DOLS estimators in this study.

\subsubsection{Frequency Domain Causality}

The current research also intends to capture the causal effects of coal consumption, financial development, globalization, and economic growth on $\mathrm{CO}_{2}$ emissions at different frequencies in South Africa. Thus, the present study employs the frequency domain causality test of Breitung and Candelon (2006). "The key distinction between the time domain method and the frequencydomain method is; the 'time-domain' method informs us where a particular change arises inside a time series, while the "frequency-domain" method evaluates the extent of a specific variation in time series" (Khan et al. 2020; Gokmenoglu et al. 2019). The frequency-domain causality test enables the removal of seasonal fluctuations in small sample data (Breitung \& Candelon, 2006).

Additionally, the frequency domain test can identify non-linearity and causality phases, while the test often facilitates the detection of causality between variables at low, medium, and long frequencies (Breitung \& Candelon, 2006). Furthermore, this technique enables us to differentiate long-term causality from short-term causality between time series.

\section{Results and Discussion}

\subsection{Results}

Table 2 presents a summary of the variables utilized. The

\begin{tabular}{|c|c|c|c|c|c|}
\hline Tests & $\mathrm{CO}_{2}$ & $\mathrm{CC}$ & FD & GLO & GDP \\
\hline Mean & 0.948 & 5.214 & -0.368 & 1.716 & 3.812 \\
\hline Median & 0.942 & 5.235 & -0.346 & 1.738 & 3.801 \\
\hline Maximum & 0.999 & 5.315 & -0.202 & 1.849 & 3.879 \\
\hline Minimum & 0.888 & 4.995 & -0.533 & 1.569 & 3.741 \\
\hline Std. Dev. & 0.031 & 0.087 & 0.110 & 0.114 & 0.046 \\
\hline Skewness & 0.044 & -0.677 & 0.047 & -0.096 & 0.137 \\
\hline Kurtosis & 2.077 & 2.552 & 1.402 & 1.206 & 1.636 \\
\hline Jarque-Bera & 1.368 & 3.223 & 4.056 & 5.151 & 3.065 \\
\hline Probability & 0.506 & 0.199 & 0.131 & 0.076 & 0.215 \\
\hline Observations & 38 & 38 & 38 & 38 & 38 \\
\hline \multicolumn{6}{|c|}{$\begin{array}{l}\text { Note: } \mathrm{CO}_{2} \text {, } \mathrm{CC}, \mathrm{FD}, \mathrm{GLO}, \mathrm{GDP} \text { depict carbon emissions, coal } \\
\text { consumption, financial development, globalization and economic } \\
\text { growth }\end{array}$} \\
\hline
\end{tabular}
skewness values for all the variables show that the parameters are normal. Furthermore, the Kurtosis values illustrate that all the variables conform to normality.
Table 2

Descriptive Statistics of variables used

The probability value of Jarque-Bera reveals that globalization does not conform to normality, while $\mathrm{CO} 2$ emissions, coal consumption, economic growth, and financial development conform to normality.

This paper utilizes both conventional unit root tests, namely $\mathrm{ADF}$ and $\mathrm{PP}$, and the more recent Zivot-Andrew (ZA) and Lee-Stratchwich (LS) unit root tests, to capture both stationarity properties and structural break of time series variables. The results of the $\mathrm{ADF}$ and $\mathrm{PP}$ test are depicted in Tables 3 and 4, respectively. The findings reveal that all the parameters are non-stationary at level, i.e. I(0). However, after taking the first difference, i.e., I(1), all the variables are found to be stationary. Furthermore, the outcomes of the ZA and LS are presented in Tables 3 and 4, respectively. The outcomes of the ZA and LS show that all the series are stationary at a mixed level i.e., I(0) and $\mathrm{I}(1)$.

Table 3

Unit-Root Tests Results of Variables at Level

\begin{tabular}{cccccc}
\hline Tests & $\mathrm{CO}_{2}$ & $\mathrm{CC}$ & $\mathrm{FD}$ & GLO & GDP \\
\hline $\mathrm{ADF}$ & -2.743 & -2.756 & -2.516 & -2.125 & -2.63 \\
$\mathrm{PP}$ & -2.971 & -2.753 & -2.979 & -1.749 & -1.725 \\
$\mathrm{ZA}$ & -4.487 & -4.698 & -4.276 & -3.604 & -3.584 \\
& {$[2003]$} & {$[2007]$} & {$[1996]$} & {$[1981]$} & {$[1990]$} \\
$\mathrm{LS}$ & $-6.01^{* * *}$ & $-7.007^{*}$ & $-6.94^{* *}$ & $-6.073^{* *}$ & $-7.685^{*}$ \\
& {$[1997]$} & {$[1997]$} & {$[1996]$} & {$[1988]$} & {$[1991]$} \\
& $\{2001\}$ & $\{2001\}$ & $\{2001\}$ & $\{2008\}$ & $\{2004\}$
\end{tabular}

Note: $1 \%, 5 \%$ and $10 \%$ represents $* * *$, and ${ }^{* * *}$ respectively. [] and $\{$ means first and second break.

Source: Authors Compilation with EViews 12

Table 4

Unit-Root Tests Results of Variables at First Difference

\begin{tabular}{cccccc}
\hline Tests & $\mathrm{CO}_{2}$ & $\mathrm{CC}$ & $\mathrm{FD}$ & $\mathrm{GLO}$ & $\mathrm{GDP}$ \\
\hline $\mathrm{ADF}$ & $-6.301^{*}$ & $-6.246^{*}$ & $-5.702^{*}$ & $-4.232^{*}$ & $-4.222^{*}$ \\
$\mathrm{PP}$ & $-6.318^{*}$ & $-6.253^{*}$ & $-5.702^{*}$ & $-3.234^{*}$ & $-4.289^{*}$ \\
$\mathrm{ZA}$ & $-7.763^{*}$ & $-7.763^{*}$ & $-6.256^{* *}$ & $-5.080^{* *}$ & $-5.980^{* *}$ \\
& {$[1993]$} & {$[1993]$} & {$[2000]$} & {$[1993]$} & {$[2009]$} \\
$\mathrm{LS}$ & $-6.69^{* *}$ & $-7.361^{*}$ & $-6.573^{* *}$ & -7.217 & $-6.185^{* *}$ \\
& {$[1990]$} & {$[1992]$} & {$[1996]$} & $*[1990]$ & {$[1993]$} \\
& $\{1994\}$ & $\{2009\}$ & $\{2001\}$ & $\{2000\}$ & $\{2006\}$
\end{tabular}

Note: $1 \%, 5 \%$ and $10 \%$ represents ${ }^{*},{ }^{* *}$, and ${ }^{* * *}$ respectively. [] and $\{$ means first and second break.

Source: Authors Compilation with EViews 12 
As the parameters are stationary at a mixed level i.e. $\mathrm{I}(0)$ and $\mathrm{I}(1)$, the ARDL bounds test proposed by Pesaran et al. (2001) is used to investigate the co-integration of $\mathrm{CO}_{2}$ emissions and the explanatory variables. The cointegration results are shown in Table 4. The outcomes from Table 5 reveal that both F-statistics and T-statistics are greater than Kripfganz and Schneider's (2018) critical value at a significance level of $1 \%$. Therefore, the study affirms that in the long run, all variables are cointegrated. Thus, the null hypothesis is not considered, indicating that there is long-term co-integration among the indicators. Accordingly, the study employs the ARDL long-run and short-run estimators to capture the impact of financial development, economic growth, coal consumption, and globalization on $\mathrm{CO}_{2}$ emissions in the long and short run. The results of the CUSUM and CUSUM squares in Figures 4 and 5 also show that the model is stable at a significance level of 5\%.

The study uses Bayer and Hanck (2013) combined the co-integration test to capture the co-integration among the variables in this analysis. The results of the Bayer and Hanck (2013) combined co-integration test are depicted in Table 6. The results show that there is evidence of longrun co-integration among the variables used in this study at a $5 \%$ level of significance, indicating that the combination of coal consumption, financial development, economic growth, globalization significantly affect $\mathrm{CO}_{2}$ emissions in the long-run. This outcome allows the present study to investigate the short-run and long-run effect of coal consumption, financial development, economic growth, globalization on $\mathrm{CO}_{2}$ emissions.

The study uses the long-run and short-run ARDL estimates to evaluate the impact of coal consumption and economic growth on environmental sustainability in South Africa after the long-run co-integration of the parameters has been established. In addition, the study also explores the role of financial development and globalization in South Africa's environmental sustainability over the period from 1980 to 2017. The results of the ARDL longrun and short-run estimations are depicted in Table 7 . The findings from the ARDL long and short-run estimation revealed that economic growth exerts a positive influence on environmental degradation. This means that by holding other indicators stable, a $0.69 \%$ rise in $\mathrm{CO}_{2}$ emissions is caused by a $1 \%$ increase in economic growth. Also, globalization exerts a positive and insignificant impact on environmental degradation in South Africa. Coal consumption is, as predicted, positively connected with $\mathrm{CO}_{2}$ emissions. It was found that a $1 \%$ rise in the usage of coal increases $\mathrm{CO}_{2}$ emissions by $1.077 \%$.

Table 5

ARDL Bounds Test Cointegration Result

\begin{tabular}{lc}
\hline F-Statistics & T-Statistics \\
\hline $5.86^{*}$ & $-5.21^{*}$
\end{tabular}

Kripfganz and Schneider (2018) critical and P-values T-statistics (CV)

LB

UB

$-2.495$

$-3.798$

$-2.843$

$-4.207$

$-5.021$ F-statistics (CV)

LB
UB 2.204 3.320

$-3.54$

3.891

3.891

3.572

5.112

Note: * represent a $1 \%$ level of significance, and CV denotes critical value. UB and LB denote a lower and upper bound critical value

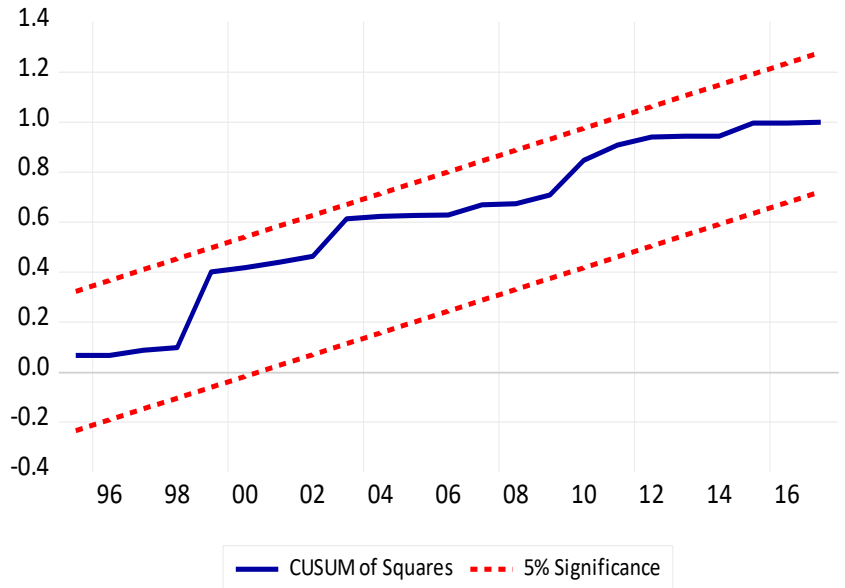

Fig 4. Stability Test Using CUSUM

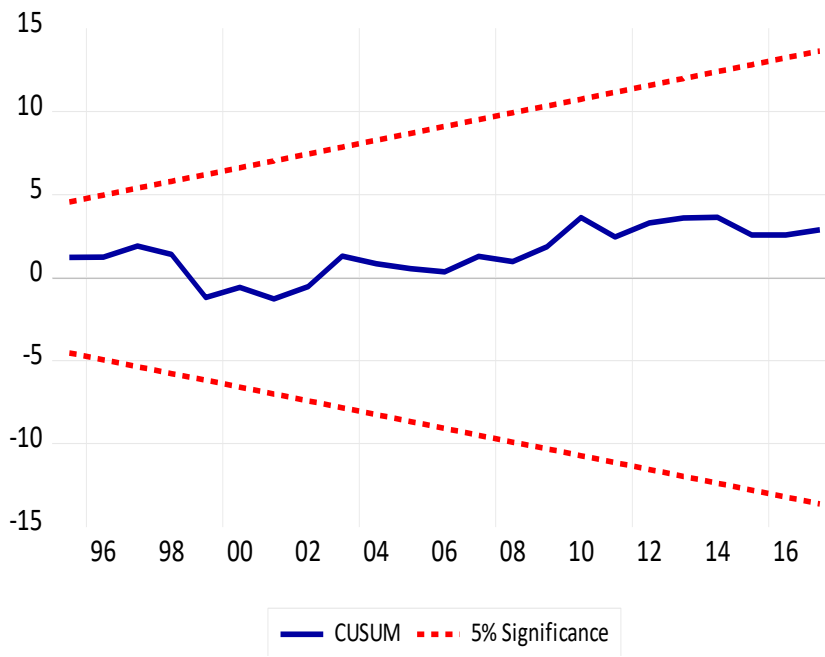

Fig 5. Stability Test Using CUSUM of Squares

Table 6

Bayer and Hack Combined Cointegration Result

\begin{tabular}{ccc}
\hline $\begin{array}{c}\text { Model } \\
\text { Specifications }\end{array}$ & $\begin{array}{c}\text { Fisher } \\
\text { Statistics }\end{array}$ & Fisher Statistics \\
\hline & EG-JOH & EG-JOH-BAN-BOS \\
$\mathrm{CO}_{2}=f(\mathrm{CC}, \mathrm{FD}$, & $14.088^{* *}$ & $27.795^{* *}$ \\
GDP, GLO $)$ & & \\
& Critical value & Critical value \\
& 10.576 & 20.143
\end{tabular}

Note: $10 \%$ and $5 \%$ level of significance is depicted by ** and *, respectively.

Source: Authors Compilation with Stata 15

Furthermore, financial development exerts a negative impact on $\mathrm{CO}_{2}$ emissions at a $5 \%$ level of significance. The findings suggest that a decrease of $0.973 \%$ in $\mathrm{CO}_{2}$ emissions is due to a $1 \%$ increase in financial development. Furthermore, the analysis used the FMOLS and DOLS estimators to check the ARDL estimator's long-run results. The findings from the FMOLS and DOLS are reported in Table 8. The outcomes show that keeping other indicators constant, a $1 \%$ increase in coal consumption and economic growth increase $\mathrm{CO}_{2}$ emissions $1.077 \%$ and $1.449 \%$ respectively.

Source: Authors Compilation with EViews 12 
Moreover, financial development exerts a negative influence on $\mathrm{CO}_{2}$ emissions, which demonstrates that a $1 \%$ increase in financial development will decrease $\mathrm{CO}_{2}$ emissions by $0.95 \%$. Nonetheless, no significant interconnection was established between globalization and $\mathrm{CO}_{2}$ emissions. These results comply with the results of the ARDL long-run estimations. The model fitness is illustrated by $R^{2}(0.98)$ and adjusted $R^{2}(0.97)$ suggesting that $98 \%$ of the changes in $\mathrm{CO}_{2}$ emissions can be explained by financial development, coal consumption, economic growth, and globalization. The remaining $2 \%$ is attributed to the error term. Furthermore, the outcomes of the diagnostic tests revealed that there is no serial correlation, residuals are normally distributed, and no misspecification in the model.

Table 7

ARDL Long-run and Short-run Results

\begin{tabular}{|c|c|c|c|c|c|c|}
\hline & \multicolumn{3}{|c|}{ Long-run Results } & \multicolumn{3}{|c|}{ Short-Run Results } \\
\hline Regressors & Coefficient & Std. Error & T-prob & Coefficient & Std. Error & T-prob \\
\hline $\mathrm{CC}$ & 1.077 & 0.199 & $2.290^{* *}$ & 1.077 & 0.315 & $4.279^{*}$ \\
\hline FD & -0.973 & 0.172 & $-2.485^{*}$ & -0.175 & 0.175 & -0.865 \\
\hline GLO & 0.231 & 0.169 & 0.569 & 0.231 & 0.207 & 0.985 \\
\hline GDP & 1.449 & 0.091 & $2.279^{* *}$ & 0.683 & 0.215 & 1.844 \\
\hline \multirow[t]{8}{*}{$\operatorname{ECM}(-)$} & & & & -0.545 & 0.081 & $-6.632^{*}$ \\
\hline & \multicolumn{3}{|c|}{$\mathrm{R}^{2}$} & 0.98 & & \\
\hline & \multicolumn{3}{|c|}{ Adj-R $R^{2}$} & 0.97 & & \\
\hline & \multicolumn{4}{|c|}{ Diagnostic Tests } & & \\
\hline & \multicolumn{3}{|c|}{$\mathrm{x}^{2} \mathrm{ARCH}$} & $1.37(0.33)$ & & \\
\hline & \multicolumn{3}{|c|}{$x^{2}$ RESET } & $2.17(0.14)$ & & \\
\hline & \multicolumn{3}{|c|}{$\mathrm{x}^{2}$ Normality } & $0.13(0.93)$ & & \\
\hline & \multicolumn{3}{|c|}{$x^{2} \mathrm{LM}$} & $1.25(0.11)$ & & \\
\hline
\end{tabular}

Note: $5 \%$ and $1 \%$ level of significance is depicted by ** and * respectively. CC, FD, GLO and GDP represents coal consumption,

financial development, globalisation, and economic growth.

Source: Authors Compilation with EViews 12

Table 8

FMOLS and DOLS Results

\begin{tabular}{ccccccc} 
& \multicolumn{3}{c}{ FMOLS } & & \multicolumn{2}{c}{ DOLS } \\
\hline Regressors & Coefficient & Std. Error & T-prob & Coefficient & Std. Error & T-prob \\
CC & 1.103 & 0.092 & $5.429^{*}$ & 1.077 & 0.003 & $3.818^{*}$ \\
FD & -0.515 & 0.031 & $-4.679^{*}$ & -0.973 & 0.075 & $-4.144^{*}$ \\
GLO & 0.274 & 0.151 & 1.236 & 0.231 & 0.042 & 0.935 \\
GDP & 1.521 & 0.155 & $5.475^{*}$ & 1.449 & 0.200 & $3.801^{*}$ \\
R & & 0.98 & & & 0.98 & \\
Adj R & & 0.97 & & & 0.97
\end{tabular}

Note: * denote $1 \%$ level of significance. CC, FD, GLO and GDP represents coal consumption, financial development, globalisation, and economic growth.

Source: Authors Compilation with EViews 12

Table 9

Frequency Domain Causality Results

\begin{tabular}{|c|c|c|c|c|c|c|}
\hline \multirow{2}{*}{ Direction of causality } & \multicolumn{2}{|c|}{ Long term Causality } & \multicolumn{2}{|c|}{ Medium-term Causality } & \multicolumn{2}{|c|}{ Short term Causality } \\
\hline & $\omega_{\mathrm{i}}=0.01$ & $\omega_{\mathrm{i}}=0.05$ & $\omega_{\mathrm{i}}=1.00$ & $\omega_{\mathrm{i}}=1.50$ & $\omega_{\mathrm{i}}=2.00$ & $\omega_{\mathrm{i}}=2.50$ \\
\hline $\mathrm{CC} \rightarrow \mathrm{CO}_{2}$ & $\begin{array}{c}<10.412> \\
(0.005) *\end{array}$ & $\begin{array}{c}<10.439> \\
(0.005) *\end{array}$ & $\begin{array}{c}<12.569> \\
(0.001) *\end{array}$ & $\begin{array}{c}<12.351> \\
(0.002)^{*}\end{array}$ & $\begin{array}{c}<12.263> \\
(0.002) *\end{array}$ & $\begin{array}{c}<12.225> \\
(0.002) *\end{array}$ \\
\hline $\mathrm{FD} \rightarrow \mathrm{CO}_{2}$ & $\begin{array}{c}<5.294> \\
(0.070) * * *\end{array}$ & $\begin{array}{c}<5.295> \\
(0.070)^{* * *}\end{array}$ & $\begin{array}{c}<0.356> \\
(0.837)\end{array}$ & $\begin{array}{c}<4.290> \\
(0.117)\end{array}$ & $\begin{array}{c}<4.654> \\
(0.097) * * *\end{array}$ & $\begin{array}{c}<4.637> \\
(0.098) * * *\end{array}$ \\
\hline $\mathrm{GDP} \rightarrow \mathrm{CO}_{2}$ & $\begin{array}{c}<0.364> \\
(0.833)\end{array}$ & $\begin{array}{c}<0.355> \\
(0.837)\end{array}$ & $\begin{array}{c}<1.094> \\
(0.578)\end{array}$ & $\begin{array}{c}<1.229> \\
(0.540)\end{array}$ & $\begin{array}{c}<1.265> \\
(0.531)\end{array}$ & $\begin{array}{c}<1.278> \\
(0.527)\end{array}$ \\
\hline $\mathrm{GLO} \rightarrow \mathrm{CO}_{2}$ & $\begin{array}{c}<0.298> \\
(0.861)\end{array}$ & $\begin{array}{c}<0.296> \\
(0.862)\end{array}$ & $\begin{array}{c}<0.685> \\
(0.709)\end{array}$ & $\begin{array}{c}<0.687> \\
(0.709)\end{array}$ & $\begin{array}{c}<0.687> \\
(0.709)\end{array}$ & $\begin{array}{c}<0.687> \\
(0.709)\end{array}$ \\
\hline \multicolumn{7}{|c|}{$\begin{array}{l}\text { Note: The values inside }<>\text { denote the Wald test statistics whereas the values inside ( ) denote p-values. } \rightarrow \text { portrays the causality } \\
\text { path. }{ }^{*} \text { and }{ }^{*} \text { represent } 1 \text { and } 10 \% \text { level of significance. } \mathrm{CO}_{2}, \mathrm{CC}, \mathrm{FD}, \mathrm{GLO} \text { and GDP represents } \mathrm{CO} 2 \text { emissions, coal consumption, } \\
\text { financial development, globalization, and economic growth. }\end{array}$} \\
\hline
\end{tabular}


After the long-run effects have been identified, the causal impacts of coal, financial development, globalization, and economic growth on $\mathrm{CO}_{2}$ emissions at various frequencies are identified in the frequency domain causality test of Candelon and Breitung (2006). As shown in Table 9, at a significance level of $1 \%$, the null hypothesis of coal consumption can be rejected in the short, medium, and long-run because coal consumption Granger causes $\mathrm{CO}_{2}$ emissions. Furthermore, in the short and long run, financial development Granger causes $\mathrm{CO}_{2}$ emissions in South Africa at a significance level of $10 \%$. Moreover, there is no causality running from economic growth and globalization to $\mathrm{CO}_{2}$ emissions at any frequency.

\subsection{Discussion}

The effect of economic growth on $\mathrm{CO}_{2}$ emissions is positive in the long run both the long-run and short-run. This suggests that economic growth deteriorates environmental quality in the long-run and short-run. This outcome corresponds with the findings of Usman et al. (2020) for the United States, Adebayo (2020) for Mexico, Awosusi et al. (2020) for the MINT economies, Kalmaz and Adebayo, (2021) for Egypt, Alola et al. (2019) for Europe's largest states, He et al. (2021) for Mexico and Kirikaleli et al. (2020) using the global economy, who established a positive linkage between $\mathrm{CO}_{2}$ emissions and economic growth. The reason for the positive effect of economic growth on environmental pollution is that the key sources for industry and agriculture are fossil fuels, which trigger environmental degradation and growth in the economy (Shabahz et al. 2020). The rise in environmental pollution is attributed to the fact that industrial growth in South Africa is linked to the expansion of infrastructure, the development of trade, and economic capitalization, which positively impact investment and economic production and thus raise energy use (Odugbesan \& Adebayo, 2020). From the results, financial development decreases $\mathrm{CO}_{2}$ emissions, and by implication increase environmental sustainability. As the level of financial development increases, economic growth is stimulated which decreases environmental pollution.

The negative relationship suggests that the maturity stage of the financial sector in South Africa has been reached as the sector allocates capital to environmentally sustainable initiatives and also encourages businesses to use new development technologies to raise output levels. This outcome is in line with the findings of Zhang et al. (2021), Rjoub et al. (2021), and Charfeddine \& Khediri (2016), who found that financial development enhances the quality of the environment. However, this outcome is not consistent with the findings of Dogan and Turkeku (2016), Usman et al. (2020), and Zafar et al. (2019) who established that financial development increases environmental degradation. The relationship between coal consumption and $\mathrm{CO}_{2}$ emissions is positive in the long-run and short-run. This is evident since South Africa is ranked $6^{\text {th }}$ globally in terms of coal consumption. South Africa is highly reliant on the energy sector, where development operations are dominated by coal use. Nearly $70 \%$ of the primary energy sources and $93 \%$ of electricity output come from coal reserves. Relative to the populace and the economy's scale, this high dependence on coal consumption is a significant factor in $\mathrm{CO}_{2}$ emissions
(Winkler, 2007). This outcome complies with the findings of Pata (2018) for Turkey and Al-Mulali et al. (2018) for selected countries.

The outcomes of the frequency domain causality test revealed one-way causality running from coal consumption and financial development to $\mathrm{CO}_{2}$ emissions which implies that both coal consumption and financial development can predict significant variation in $\mathrm{CO}_{2}$ emissions in South Africa. These outcomes align with the study of Kirikaleli et al. (2020) for Turkey, Usman et al. (2020) for the USA, and Shahbaz et al. (2020) for South Africa.

\section{Conclusion}

It is crucial to identify the effect of globalization and coal consumption on environmental degradation in South Africa, as the country is one of the largest $\mathrm{CO}_{2}$ emitters globally, and also to examine the roles of financial development and economic growth. Therefore, the present study employed the ARDL bounds test using Kripfganz and Schneider's (2018) critical value, ARDL long and short-run estimations, and FMOLS and DOLS. Furthermore, the frequency domain causality test was used to capture the causal linkage between the series in the short run, medium run, and long run. The empirical outcomes revealed an insignificant interconnection between globalization and environmental degradation, while economic growth exerts a positive impact on environmental degradation. Furthermore, financial development exerts a negative impact on environmental degradation. In general, the study found that the growth of the banking sector, which offers per-capita access to private sector domestic finance, aims to mitigate carbon emissions. This means that by implementing financial reforms, financial development can be used as a tool to preserve the quality of the environment. Moreover, coal use significantly contributes to the degradation of environmental sustainability. Furthermore, the findings from the frequency domain causality test revealed that coal consumption Granger causes $\mathrm{CO}_{2}$ emissions at different frequencies while financial development Granger causes $\mathrm{CO}_{2}$ emissions in the short run and long run.

In this respect, a sound policy agenda should be developed that provides long-term value for lowering GHGs and continuously encourages the creation of emerging technology that contributes to a less carbonintensive economy. Furthermore, the growth of a sufficient stock market may be another valuable policy tool that can be implemented. This is because businesses can reduce the liquidity risk that can mobilize the funds needed by diversification of a portfolio that is particularly essential in the long-term growth of a robust technology base. In addition, concerning financial development and environmental deterioration, the study contends that higher levels of development of the financial sector and trade transparency encourage technical advances by increasing R\&D expenditure on energy efficiency, resulting in energy savings, and thus reducing pollution. Also, South Africa should embrace policies that encourage energy consumers to shift toward renewable energy.

Although the study used substantial econometric techniques, a limitation of the study is the unavailability 
of data beyond 2017. Furthermore, this study used $\mathrm{CO}_{2}$ as the proxy of environmental quality. Thus, other studies should examine these interconnections by utilizing other proxies of environmental degradation.

\section{References}

Abdullah, W. M. Z. B. W., Zainudin, W. N. R. A., Ishak, W. W. B. M., Sulong, F., \& Zia Ul-Haq, H. M. (2021). Public Participation of Renewable Energy (PPRED) Model in Malaysia: An Instrument Development. Int. J. Ren. Energ. Dev., 10(1), 119-137.

Adebayo, T. S., \& Odugbesan, J. A. (2020). Modeling CO 2 emissions in South Africa: empirical evidence from ARDL based bounds and wavelet coherence techniques. Environ. Sci. Pollut. Res., 1-13.

Adebayo, T. S. (2020). Revisiting the EKC hypothesis in an emerging market: an application of ARDL-based bounds and wavelet coherence approaches. SN App. Sci., 2(12), 115.

Adebayo, T.S. (2021). Do $\mathrm{CO}_{2}$ emissions, energy consumption and globalization promote economic growth? Empirical evidence from Japan. Environ Sci Pollut Res., 34-28. https://doi.org/10.1007/s11356-021-12495-8

Adebayo, T., Akinsola, G., Odugbesan, J., Olanrewaju, V. (2021). Determinants of Environmental Degradation in Thailand: Empirical Evidence from ARDL and Wavelet Coherence Approaches. Pollut., 7(1), 181-196. doi: 10.22059/poll.2020.309083.885

Adedoyin, F. F., Gumede, M. I., Bekun, F. V., Etokakpan, M. U., \& Balsalobre-lorente, D. (2020). Modelling coal rent, economic growth and $\mathrm{CO} 2$ emissions: Does regulatory quality matter in BRICS economies?. Sci. Tot. Environ., $710,136284$.

Al-mulali, U., \& Che Sab, C. N. B. (2018). The impact of coal consumption and $\mathrm{CO} 2$ emission on economic growth. En. Sour., Part B: Econ., Plann., and Pol., 13(4), 218-223.

Akinsola, G. D., \& Adebayo, T. S. (2021) Investigating the Causal Linkage Among Economic Growth, Energy Consumption and CO 2 Emissions in Thailand: An Application of the Wavelet Coherence Approach. Int. J. Ren. Energ. Dev., 10(1).

Alola, A. A., Yalçiner, K., Alola, U. V., \& Saint Akadiri, S. (2019). The role of renewable energy, immigration and real income in environmental sustainability target. Evidence from Europe largest states. Sci. Tot. Environ., 674, 307-315.

Attiaoui, I., Toumi, H., Ammouri, B., \& Gargouri, I. (2017). Causality links among renewable energy consumption, $\mathrm{CO}_{2}$ emissions, and economic growth in Africa: Evidence from a panel ARDL-PMG approach. Environ. Sci. Pollut. Res., 24(14), 13036-13048.

Awosusi, A. A., \& Adeshola, I., \& Adebayo, T. S. (2020). Determinants of $\mathrm{CO} 2$ Emissions in Emerging Markets: An Empirical Evidence from MINT Economies. Int. J. Ren. Energ. Dev., 9(3).

Bayer, C., \& Hanck, C. (2013). Combining non-cointegration tests. J. of Tim. Ser. Anal., 34(1), 83-95.

Bekun, F. V., Emir, F., \& Sarkodie, S. A. (2019). Another look at the relationship between energy consumption, carbon dioxide emissions, and economic growth in South Africa. Sci. Tot. Environ., 655, 759-765.

Belaid, F., \& Youssef, M. (2017). Environmental degradation, renewable and non-renewable electricity consumption, and economic growth: Assessing the evidence from Algeria. Energ. Pol., 102, 277-287.

Bento, J. P. C., \& Moutinho, V. (2016). CO2 emissions, nonrenewable and renewable electricity production, economic growth, and international trade in Italy. Ren. Sustain. Energ. Rev., 55, 142-155.

Bildirici, E. M., \& Bakirtas, T. (2016). The relationship among oil and coal consumption, carbon dioxide emissions, and economic growth in BRICTS countries. J. of Ren. and Sustain. Energ., 8(4), 045903.

Charfeddine L, Kahia M (2019) Impact of renewable energy consumption and financial development on $\mathrm{CO} 2$ emissions and economic growth in the MENA region: a panel vector autoregressive (PVAR) analysis. Ren. Energ. 139:198-213.

Charfeddine, L., \& Khediri, K. B. (2016). Financial development and environmental quality in UAE: Cointegration with structural breaks. Ren. Sustain. Energ. Rev., 55, 1322-1335.

Di Gianfrancesco, A. (2017). Worldwide overview and trend for clean and efficient use of coal. In Materials for UltraSupercritical and Advanced Ultra-Supercritical Power Plants (pp. 643-687). Woodhead Publishing.

Dogan, E., \& Ozturk, I. (2017). The influence of renewable and non-renewable energy consumption and real income on $\mathrm{CO}$ 2 emissions in the USA: evidence from structural break tests. Environ. Sci. Pollut. Res., 24(11), 10846-10854.

Fei, L., Dong, S., Xue, L., Liang, Q., \& Yang, W. (2011). Energy consumption-economic growth relationship and carbon dioxide emissions in China. Energ. Pol., 39(2), 568-574.

Frankel, J. A., \& Romer, D. H. (1999). Does trade cause growth?. Amer. Econ. Rev., 89(3), 379-399.

He, X., Adebayo, T. S., Kirikkaleli, D., \& Umar, M. (2021). Analysis of Dual Adjustment Approach: ConsumptionBased Carbon Emissions in Mexico. Sust. Prod. and Con. 4(3), 10-26

Inglesi-Lotz, R., \& Dogan, E. (2018). The role of renewable versus non-renewable energy to the level of $\mathrm{CO} 2$ emissions a panel analysis of sub-Saharan Africa's Big 10 electricity generators. Ren. Energ., 123, 36-43

International Monetary Fund, (2019) https://data.imf.org/?sk=1C28EBFB-62B3-4B0C-AED3048EEEBB684F

Jian J, Fan X, He P, Xiong H, Shen H (2019) The effects of energy consumption, economic growth and financial development on CO2 emissions in China: a VECM Approach. Sustain., 11(18): 4850

Joshua, U., Bekun, F. V., \& Sarkodie, S. A. (2020). New insight into the causal linkage between economic expansion, FDI, coal consumption, pollutant emissions and urbanization in South Africa. Environ. Sci. Pollut. Res., 1-12.

Kalmaz, D. B., \& Adebayo, T. S. (2021). Determinants of CO 2 emissions: empirical evidence from Egypt. Environ. Eco. Stat., 1-24.

Kalmaz, D. B., \& Kirikkaleli, D. (2019). Modeling CO 2 emissions in an emerging market: empirical finding from ARDL-based bounds and wavelet coherence approaches. Environ. Sci. Pollut. Res., 26(5), 5210-5220.

Kalayci, C. (2019). The impact of economic globalization on CO2 emissions: the case of NAFTA countries. Int. J. of Energ. Econ. and Pol., 9(1), 356.

Khan, M. K., Teng, J. Z., \& Khan, M. I. (2019). Effect of energy consumption and economic growth on carbon dioxide emissions in Pakistan with dynamic ARDL simulations approach. Environ. Sci. Pollut. Res., 26(23), 23480-23490.

Khan, M. K., Teng, J. Z., Khan, M. I., \& Khan, M. O. (2019). Impact of globalization, economic factors and energy consumption on CO2 emissions in Pakistan. Sci. Tot. Environ., 688, 424-436.

Khan, M. T. I., Yaseen, M. R., \& Ali, Q. (2017). Dynamic relationship between financial development, energy consumption, trade and greenhouse gas: comparison of upper middle income countries from Asia, Europe, Africa and America. J. of Clean. Prod., 161, 567-580.

Kirikkaleli D, Adebayo TS. (2020). Do renewable energy consumption and financial development matter for environmental sustainability? New global evidence Sustain. Dev., https://doi.org/10.1002/sd.2159

Kirikkaleli, D., \& Kalmaz, D. B. (2020). Testing the moderating role of urbanization on the environmental Kuznets curve: empirical evidence from an emerging market. Environ. Sci. Pollut. Res., 27(30), 38169-38180. 
Citation: Adebayo, T.S., Kirikkaleli, D., Adeshola, I., Oluwajana, D., Akinsola, G.D., Osemeahon, O.S. (2021) Coal Consumption and Environmental Sustainability in South Africa: The role of Financial Development and Globalization. Int. Journal of Renewable Energy Development, 10(3), 527-536, doi: 10.14710/ijred.2020.34982

$\mathrm{P}$ a g e $\mid 536$

Kirikkaleli, D., Adebayo, T. S., Khan, Z., \& Ali, S. (2020). Does globalization matter for ecological footprint in Turkey? Evidence from dual adjustment approach. Environ. Sci. Pollut. Res., 1-9.

Liu, M., Ren, X., Cheng, C., \& Wang, Z. (2020). The role of globalization in CO2 emissions: A semi-parametric panel data analysis for G7. Sci. Tot. Environ., 718, 137379.

Magazzino, C., Bekun, F. V., Etokakpan, M. U., \& Uzuner, G. (2020). Modeling the dynamic Nexus among coal consumption, pollutant emissions and real income: empirical evidence from South Africa. Environ. Sci. Pollut. Res., 27(8), 8772-8782.

Nguyen, T., \& Le, Q. (2020). Impact of globalization on CO2 emissions in Vietnam: An autoregressive distributed lag approach. Dec. Sci. Lett., 9(2), 257-270.

Odhiambo, N. M. (2016). Coal consumption and economic growth in South Africa: An empirical investigation. Energ. \& Environ., 27(2), 215-226.

Odugbesan, J. A., \& Adebayo, T. S. (2020). The symmetrical and asymmetrical effects of foreign direct investment and financial development on carbon emission: evidence from Nigeria. SN App. Sci., 2(12), 1-15.

Onyibor, K., \& Akinsola, G. D., \& Adebayo, T. S. (2020). The impact of major macroeconomic variables on foreign direct investment in Nigeria: evidence from a wavelet coherence technique. SN Bus. \& Econ., 1(1), 1-24.

Ozatac, N., Gokmenoglu, K. K., \& Taspinar, N. (2017). Testing the EKC hypothesis by considering trade openness, urbanization, and financial development: the case of Turkey. Environ. Sci. Pollut. Res., 24(20), 16690-16701.

Pata, U. K. (2018a). The effect of urbanization and industrialization on carbon emissions in Turkey: evidence from ARDL bounds testing procedure. Environ. Sci. Pollut. Res., 25(8), 7740-7747.

Pata, U. K. (2018b). The influence of coal and noncarbohydrate energy consumption on $\mathrm{CO} 2$ emissions: revisiting the environmental Kuznets curve hypothesis for Turkey. Energ., 160, 1115-1123.

Pata, U. K. (2018c). Ren. Energ. consumption, urbanization, financial development, income and $\mathrm{CO} 2$ emissions in Turkey: testing EKC hypothesis with structural breaks. J. of Clean. Prod., 187, 770-779.

Phillips, P. C., \& Hansen, B. E. (1990). Statistical inference in instrumental variables regression with I (1) processes. The Rev. of Econ. Stud., 57(1), 99-125.

Rjoub, H., Odugbesan, J. A., Adebayo, T. S., \& Wong, W. K. (2021). Sustainability of the Moderating Role of Financial
Development in the Determinants of Environmental Degradation: Evidence from Turkey. Susain.., 13(4), 1844.

Raza, M. Y., \& Shah, M. T. S. (2019). Analysis of coal-related energy consumption in Pakistan: an alternative energy resource to fuel economic development. Environ., Dev. and Sustain., 1-22.

Saidi K, Mbarek MB (2017). The impact of income, trade, urbanization, and financial development on CO 2 emissions in 19 emerging economies. Environ. Sci. Pollut. Res., 24(14):12748-12757.

Sarkodie, S. A., \& Adams, S. (2018). Ren. Energ., nuclear energy, and environmental pollution: accounting for political institutional quality in South Africa. Sci. Tot. Environ., 643, 1590-1601.

Shahbaz, M., Tiwari, A. K., \& Nasir, M. (2013). The effects of financial development, economic growth, coal consumption and trade openness on CO2 emissions in South Africa. Energ. Pol., 61, 1452-1459.

Stock, J. H., \& Watson, M. W. (1993). A simple estimator of cointegrating vectors in higher order integrated systems. Econometrica: J. of the Econ. Soc., 783-820.

Umar M, Ji X, Kirikkaleli D, Xu Q (2020) COP21 Roadmap: Do innovation, financial development, and transportation infrastructure matter for environmental sustainability in China? J. Environ. Manag., 271:111026.

Usman O, Akadiri SS, Adeshola I (2020) Role of Ren. Energ. and globalization on ecological footprint in the USA: implications for environmental sustainability. Environ. Sci. Pollut. Res., 27:1-13.

Wang, S. S., Zhou, D. Q., Zhou, P., \& Wang, Q. W. (2011). CO2 emissions, energy consumption and economic growth in China: A panel data analysis. Energ. Pol, 39(9), 4870-4875.

World Bank.

worldbank.org/en/798731523331698204/South-AfricaEconomic-Update-April-2018. Retrieved 10 December 2020.

Word Development Indicators (WDI, 2019) https://databank.worldbank.org/source/world-development indicators\#advancedDownloadOptions. Retrieved 10 December 2020

World Economic Outlook Database, November (2020). IMF.org. Inter. Mon. Fun. Retrieved 19 November 2020.

Zhang, L., Li, Z., Kirikkaleli, D., Adebayo, T. S., Adeshola, I., \& Akinsola, G. D. (2021). Modeling CO 2 emissions in Malaysia: an application of Maki cointegration and wavelet coherence tests. Environ. Sci. Pollut. Res., 1-15. 